\title{
Implementation of Theory $\mathrm{Z}$ William Ouchi in Pesantrenprenur: Study on Organizational Culture
}

\author{
Heri Cahyo Bagus Setiawan*, Aries Kurniawan and Beni Dwi Komara
}

\author{
Study Program of Entrepreneurship, Economy and Business Faculty, Universitas Muhammadiyah Gresik \\ *Corresponding authoremail: hericbs@umg.ac.id
}

\begin{abstract}
Life-time employment, Slow promotion and evaluation (evaluation and promotion process is relatively slow); Non spesialized career path (wide career path); Collective responsibility (responsibility as a group); Implicit control mechanism (control attached) and Wholistic concern (thorough attention to employees) is a basic principle Theory $\mathrm{Z}$ was initiated by William Ouchi. His findings, surprising the Americans until there is concern at the decline in the level of competitive advantage in global business. What's wrong with the findings Ouchi? He dissected the Japanese culture. As a result, social and organizational culture in Japan a high potential to affect productivity. How with in schools? Culture (social and cultural organizations) in boarding resembles, --although not the same-- with Japanese culture. When observation and deepening in the field, it seems schools we observed a tendency to follow the seven basic principles wake William Ouchi. The result is surprising: (1) adherence of communal culture pesantren. Organizational decision made jointly (decision true fraternity) with the blessing kiai (submission to kiai without reserve); (2) Decision-making at the school rather sluggish. They are more likely to communicate with a group of true brotherhood together. Of course the decision before the run, first performed istikharah process (for guidance from God) by their mutual kiai; (3) Treating the students are not within the boundaries of formal ties, but ties mitsaqan galidhan (a strong emotional bond, a bond child and father). Not only limited to humane treatment, but entered the bond niches ukhrawiyah (akherat) up to the rest of their family; (4) The monitoring is not just "sticks", but rather from the inherent (bathiniah supervision); (5) Responsibiltinya not only the group, but rather of a group, namely "shared responsibility in a group tied true brotherhood". Love, pleasure and sorrow felt together; (6) They work istiqamah-qana'ah (accept what their position), do not move to another company with a higher position (better acchievement). Do not dismiss unilaterally if no shar'i reason (violating religious norms). If dlam carries on business in schools experiencing problems, they prefer to lower wages. Avoiding lay-offs in the activities of the organization. Even, together they agreed to work without being rewarded. Of course spiritualistic underlying motivation. Loyalty to corp schools is more important than profession. Promotion and evaluation tends to be slow. Salary increase is not based on merit, but on average formula of students; (7) Do not take the path of a career, but more likely the work done by their compromise with the more senior group. Work-disk of his job is more dynamic because it is done for a compromise. Of course according to their expertise. As a result, schools cultural factors (social and organizational culture) greatly affect the productivity performance of operating in schools, compared with similar conventional company. Loyalty to corp schools is more important than profession. Promotion and evaluation tends to be slow. Salary increase is not based on merit, but on average formula of students.
\end{abstract}

Keywords: pesantrenpreneur (islamic boarding school based on entrepreneurship, organizational culture, theory $Z$

\section{INTRODUCTION}

The basic principle is the formation theory stems from concerns $\mathrm{Z}$ William Ouchi, that at the beginning of the industrial era, most of them excessively put and "deification" of technology and capital to be the only important in the management process. They deny appreciation, and the role of the human factor. 1974 Richard Johnson and William Ouchi of the Graduate School of Businnes At Stanford University launched an article in the Harvard Bussines Review: "Made in America under Japanese Management". An article highlighting the growing productivity gap between Japanese companies-American, where Japan increasingly superior. Of course the article is surprising and concerns of Americans over the downward trend of the level of competitive advantage in global business.

The reality is, since the end of World War II, Americans were originally underestimated economy Japan, was found to show excellent results. Japan's economy soared very quickly and dramatically (great lep forward) are not taken into account America. In the 1990s-come per capita in Japan is 23 570 US dollars in the appeal that reached 21653 dollars. A figure that is quite surprising. A study explains that Japanese cultural factors (social and organizational culture) influence produktitfitas. Wiliiam Ouchi doing research on a raft line American company in Atlanta. A total of 35 workers working American women transistor panel through the stages that have been determined. In Tokyo, which is located 7,000 miles from Atlanta on the 
same branch of the company, 35 Japanese women workers also do the same work with the same technology and procedures. But the result, Japanese women worker productivity is $15 \%$ higher than American women workers.

William Ouchi also investigated at Sonny factory in San Diego, California, about 200 American workers assemble 17 and 19 inch TV through assembly lines, technology and the same procedure with the factory in Japan. It turns out, the same productivity. To ensure results, Wiliiam Ouchi conducting interviews in 20 Japanese companies operating in the United States. The result, in many cases they result in higher productivity than American companies are similar. Japanese woman worker productivity is $15 \%$ higher than American women workers. William Ouchi also investigated at Sonny factory in San Diego, California, about 200 American workers assemble 17 and 19 inch TV through assembly lines, technology and the same procedure with the factory in Japan. It turns out, the same productivity. To ensure results, Wiliiam Ouchi conducting interviews in 20 Japanese companies operating in the United States.

The result, in many cases they result in higher productivity than American companies are similar. Japanese woman worker productivity is $15 \%$ higher than American women workers. William Ouchi also investigated at Sonny factory in San Diego, California, about 200 American workers assemble 17 and 19 inch TV through assembly lines, technology and the same procedure with the factory in Japan. It turns out, the same productivity. To ensure results, Wiliiam Ouchi conducting interviews in 20 Japanese companies operating in the United States. The result, in many cases they result in higher productivity than American companies are similar. technology and the same procedure with the factory in Japan. It turns out, the same productivity. To ensure results, Wiliiam Ouchi conducting interviews in 20 Japanese companies operating in the United States. The result, in many cases they result in higher productivity than American companies are similar. technology and the same procedure with the factory in Japan. It turns out, the same productivity. To ensure results, Wiliiam Ouchi conducting interviews in 20 Japanese companies operating in the United States. The result, in many cases they result in higher productivity than American companies are similar.

The basic framework of the application of the principles of Theory Z, namely: Life-time employment(Long-term employment); Slow promotion and evaluation (evaluation and promotion process is relatively slow); Non spesialized career path (wide career path);Consensual decision making (Decision-making by consensus); Collective responsibility(Responsibility in the group); Implicit control mechanism (control attached) and Wholistic concern (thorough attention to employees) is a basic principle that popularized Theory Z William Ouchi.

His findings, surprising the Americans to the point that concerns the decline of the level of competitive advantage in global business. What's wrong with the findings Ouchi? He dissected the Japanese culture. As a result, social and organizational culture in Japan a high potential to affect productivity. Bagimana with at the schoolbased entrepreneurship?

\section{RESEARCH METHOD}

The method is the study of how one can achieve the objective truth. In fact, the method of the English word derived from the Greek words meta (follow) and hodos (road). Thus, the "method" implies that in order to achieve a goal, one must follow a certain way.

Design thinking is a recurring process that is driven by empathy, which develops solutions through prototyping and testing until the solutions according to the needs of the stakeholders involved.

In this case I also use the method of literature or literature research. The authors also draw and integrating ideas to make conclusions synthesized. In this article, the authors use several sources of references from several journals and books as references. In particular, the book Theory $\mathrm{Z}$ by William Ouchi is the main source in writing this article.

\section{RESULTS \& DISCUSSION}

Before explaining about the culture of communal schools and Theory $\mathrm{Z}$ in boarding schools, first raised a fleeting glimpse of the Islamic boarding school that our observations. Recognizing the existence and culture of schools will be easier in the application that is packaged Theory $\mathrm{Z}$ William Ouchi. There is an interesting side while Theory $\mathrm{Z}$ organizations associated in the life of schools. At least, there are cultural similarities, though not always the same between boarding culture with Japanese culture.

\subsection{Pesantren Mukmin Mandiri Entrepreneur}

This pesantren is one entrepreneur pesantren in Indonesia which is engaged in the coffee industry. A boarding school is different from most schools in Indonesia. Provide religious education, as well as providing economic empowerment of students. 
Accelerating economy and the demands of the market-oriented education, boarding schools and educational change requires vision, mission and orientation. The reality, almost $90 \%$ of pesantren in Indonesia, still preoccupied with religious issues (tafaqquh fid-din), has not teach entrepreneurship. Changing economic empowerment-oriented thinking (tafaqquh fit-tijarah) depending on the pesantren. The role of pesantren kiai very large in empowerment.

Enlightenment requires a long process. Carried out continuously by all those who care about the survival of future schools. A debate that is long and has never finished on changes in vision, missionoriented boarding entrepreneurship orientation. Although not all kiai minded fanatics, some of which can accept the changes. They were fanatics, argues that changing the orientation of boarding an attempt to obscure the noble values of pesantren.

Swift currents of modernization, technology, acceleration of economic and demands empowerment of human qualities. The human factor is very important and a driver of increased productivity boarding. Wiiliam Ouchi, with his Theory Z puts the "human" as an important factor in the management process. These factors, it is still possible there is an open space among the pesantren kiai to accept changes pesantren education oriented economic empowerment. Reorientation is an urgent and absolute demands implemented.

Islam teaches a Muslim should have a strong economic provisions for the running of worship. Worship according to the conception of Islam there are two: First, ghairu maghdha (such as prayer, fasting, etc.). Second, worship ghairu mahdhah (such as zakat, alms, etc.). Call it, for example, the teachings of the hajj and zakat (alms) in the Qur'an: "exert prayers and alms..." and "shall be executed Muslim hajj if it has the ability to more economically ...". Call another example: "Do you leave your offspring in a state of weakness (poor) economy ..." and the Hadist of the Prophet Muhammad (Nabi Muhammad): "A strong believer in the economy, more beloved to Allah than a weak believer economically." The Prophet Muhammad SAW a trade visit to Romania, he said: "Learn to you to get to China". Prophet Muhammad was not only present himself as a prophet, but also an exporter and importers (traders). History shows that when the Prophet proposed marriage to Siti Khadidjah ra, there is a spectacle that stunned friends. He mentioned dowry (the love) of the Prophet Muhammad in the form of 150 animals Onta (Rp. 6.75 billion, -). A nominal rates are not few in number. Prophet Muhammad never made a visit to Romania and China trade.

The two countries have great potential in the fields of politics and economics. Perlawatan trade inspires contemplation and exemplary. there is a spectacle that stunned friends. He mentioned dowry (the love) of the Prophet Muhammad in the form of 150 animals Onta (Rp. 6.75 billion). A nominal rates are not few in number. Prophet Muhammad never made a visit to Romania and China trade. The two countries have great potential in the fields of politics and economics. Perlawatan trade inspires contemplation and exemplary. there is a spectacle that stunned friends. He mentioned dowry (the love) of the Prophet Muhammad in the form of 150 animals Onta (Rp. 6.75 billion, -). A nominal rates are not few in number. Prophet Muhammad never made a visit to Romania and China trade. The two countries have great potential in the fields of politics and economics. Perlawatan trade inspires contemplation and exemplary.

Conception and views on economic empowerment had also been initiated by Hadratusy Sheikh Hashim al-Asyari, founder of NU (Nahdlatul Ulama) had a clear conception of the establishment of NU. He said: "NU built on four (4) pillars: AnNahdlatul Ulama (cadre of scholars), An-Nahdlatul Siyasah (cadre politics and politicians), AnNahdlatul Risalah (cadre media), and An-Nahdlatul Tujjar (cadre trade / businessman).

The conception of placing the human position as something decisive in the process of boarding organizational management. The formation of the character into something that is a tradition among schools. Pesantren culture that puts the "man" in a strategic position to be changed, redirected, and developed into an organization's productivity thrust boarding. Not surprisingly, before William Ouchi the Theory $\mathrm{Z}$ about organizational culture of Japan, at the school since the first entrenched and become a distinctive culture. Only, our observations may have been no studies that focus raise the culture of schools by applying the Theory Z William Ouchi. Pesantren culture that affect the management structure and organizational productivity boarding.

\subsection{Human Factors In Management Process}

Thought that change the orientation of the school and explore the incredible cultural treasures inherent and ingrained, become a great asset wealth and boarding. If driven economy will give birth to a new economic power in the Republic of Indonesia. Middle-class economic power-down will grow stronger. Pesantren will be instrumental not only 
from the political, socio-cultural, but rather the strengthening of economic and humanitarian. In that context, the human is the most important factor in the management process. Entrepreneurial management at the school put the "man" proportional and humane. Provision of space confidence (trust), familiarity, (initimacy) and flexibility (subtlety) in the conduct of economic activity is not foreign in the pesantren community.

In fact, it has become a culture that melakat and condensed among students and kiai. Pesantren communal culture is a reflection of the basic principle in the formation theory built $\mathrm{Z}$ William Ouchi. A culture that believes that humans are not the means of production, but rather a boarding wealth and assets to be managed and developed to achieve excellence and productivity. Man as the main resource is the driving force kewiraushaan in schools. Therefore, the development of human resources was not as a means of achieving the goal, but at the same time an objective in itself. If developing superior human resources, the objectives of the business schools themselves will be achieved.

\subsection{Upholding the Dignity of Humanity}

Productivity that uphold the values of human dignity is an organization of Management demands. Technology and capital is not the only factor of production tools that accelerate the economy. Although previously, the company becomes a variable determining factor. All management functions pendinamisan must serve the interests of those variables.

Zaman kept rolling, along with shifts and changes the researchers found. When the era of admiration for the technology began to decrease, approximately 1930 -, depression outstanding at the beginning of the decade. Technology is not a guarantee of human welfare. Along with the "big event" that, Tim Mayo in the Hawthorn obtain interesting results. Findings that require people to rethink assumptions about human $\mathrm{X}$. And so on, until the Theory Z Wiliiam Ouchi. Man with all the characteristics of the surrounding is an important factor in increasing productivity. Productivity uphold the noble values of humanity mertabat.

The formation of character do before their employees (students) carry out business activities in schools. Characters formed together students and kijaji through in study, istighasah and deepening of religious plurality treasures. This media is very effective awaken human consciousness. When human consciousness present themselves as subjects for his actions. On the contrary, "unconsciousness" it means the disappearance of the taste of subjectivity. In the "unconsciousness," the man fettered by formalism or the like. Unconsciousness occurs when people are not in a capacity to organize and manage his life. When they get into the territory of the drowning, whether it be private living area, or a religious belief or a doctrine doktin-even or whatever is causing the drowning man.

Borrow a phrase from Marx, poverty and oppression make people lose consciousness. Human injustice gripping system such that man as if no longer be the owner of his life. Marxian philosophy is often referred to as reviving the philosophy that "consciousness" of man. It was a tradition boarding school, students formed the character of communal culture that surrounded. Human culture continues to grow. Humans historically and this is apparent in the culture. In the cultures, the human pilgrimage. As of the history of human culture are constantly looking for perfection. Pilgrimage always presupposes mengapai longing for something today, at this time, which has not been achieved. Call it, for example, work is God's call. Working as a manifestation of worship.

Any religion give appreciation. Work is an integral part of human dignity. In other words, that the work is not just the activity that produces something or making money. Work is a spark of human dignity. The sublime dignity of human ideals. Dignity that must be respected when making workplace rules. Rules should be made not only as formulated in the political or economic-business interests alone, but must be able to defend the dignity of humanity. He will find himself more humane work. Discover the beauty of the work. The beauty of working in human survival itself. Work rules is not only focused on the distribution of wages or benefits, career development, accommodate moments of holidays or leave, pemberiaan working hours or overtime humane, but more of that rule. Regulations on relations more humane among those concerned. Employment system should reflect the humane system.

A system that allows the conservation of human labor in the future. Work not only receive his current salary, but how would that work can give a guarantee that human beings can live well in the future. Life when she is no longer able to do a lot of things because the energy is up. That is the work of justice. Justice working system that allows a guarantee of the future. Therefore, the work is an essential part of human life itself.

The students work is not limited in time (longtime). There are no restrictions at this time, no means deny or "drown" the noble values of human dignity. 
They work in a professional, loyal and dedicated. Work is essentially in the framework of religious fulfillment. The motivation was getting stronger and beat other interests. Of course, it will affect the productivity that uphold the values of human dignity. If the character is formed, a sense of having schools together will grow (sense of belonging). Kiai only positioned itself as a motivator. Kiai is not positioning itself as the owner of pesantren (major share holder), but no more than those who have a religious intellectual who has authority religiosity. The Authority will give birth to submission without reserve. Not a forced submission, but submission in accordance with their conscience. Kiai relations students and the environment is very typical. Relationships such as children and the father, a loving and nurturing. The relationship that creates confidence (trust), intimacy (intimacy), and flexibility (subtlety). Relationship as the basic skeleton formation raised Theory Z William Ouchi.

When the company experienced a critical condition, schools do not impose layoffs (Termination) and lay off. In the perception of schools, layoffs is a culture that is not "well-ethical". Neither is it that all forms of human activity wants to chase. The human will obviously always want to win favor. Infamy will never be the object of direct human. Human thought or idea always pursue goodness. Kepandaiaan devotion humans have the intention of goodness. Therefore, both are values pursued by human action. There is a way and other ways to cope. Various efforts, approaches and humane actions carried out for the recovery effort.

Pesantren culture is participatory culture. Among students, kiai and communities happen communal typical relationship. A relationship of mutual respect, respecting and upholding human dignity. The process of giving birth relationships compliance. Students to kiai submission without reserve. The submission process is an essential feature of the students and the embodiment of traditionalist Islamic groups. First, the relationship between the kiai and students or followers there is a pattern of internal relations very strong community and closely. Kiai relationship, students and the environment nurtured well. A pattern of relationships that are formed of traditions and customs that are not formalistic, guyub, mutual respect, and filled with the simpleness. Placing kiai's position on the place of honor and has a traditional authority. Authority to create a strong adherence structure. Secondly, the ideological context, there is an ideological attachment ahlussunah wal Jamaah. This ideology is able to form emotional ties in the community. More remarkable, the bond led to fanaticism and orthodoxy group.

Geertz, for example, called the conservative and fanatical groups. Third, maintain and develop the traditional values. Values are rooted in society on religious grounds as justification. For example, the ceremony slametan (kenduren) that is packaged in such a way into a variety of shapes walimah inserted with a series of activities manaqiban, marhabanan, tahlilan and sedekahan. Fourth, the strength of the authority of kiai among traditionalist Muslims. Authority was highly correlated with adherence culture or group of students-kijaji primordial among traditional communities.

Kiyai (leader) in the sense of age and intellectual capacity occupy religious high authority. They became his role model and earn the respect of the people in their environment. Respect for his wisdom. Kiai or anyone who has the wisdom is he who will not lack anything in his life. Wisdom is the fullness of human life itself. Wisdom can not be propped up by thirst his mind. Everything thirst for wisdom can only be filled by God. Wisdom was not in the form of sentences or words comforting. Wisdom is love itself. There is no love that pursued by humans than perfect love, was the Love itself.

\subsection{Becoming More Human Self}

The evaluation process and the cadre is done slowly, gradually and naturally. May seem slow, but its meaning is very large. One side, the culture of trigger harder to do the job. The other hand, the principle of steadfastness and qana'ah (receive work-is) that rages within him. For them there is a conviction, the longer perform devotion, demonstrate compliance to the kiai. Apparently, William Ouchi research on trends in the Japanese employees working until retirement in the company and undergo promotional slowly, similar to a boarding school culture. Culture that gave birth to productivity and to influence organizational management schools.

The company's relationship with workers do with the principle of kinship. When incentives and working treatment is given and treated humanely. At that time, people will find themselves increasingly inhumane. The place and the work environment is created humanely. The room work should not be understood and interpreted narrowly as a place to do something. The work space is a space that creates creativity. The reason this allows the company to be conditioned work space into ambiente. The work space that inspires humane. Not just effective, but also genuitas production.

Culture schools do not take a specialized career path. They tend to do a job rotation (moving 
departments). Uniquely, the transfer of the work done for a compromise by themselves with a more senior group. They often communicate. Therefore, man has a communicative capacity. When a man works he not only produce something, but he also communicate himself and -karenanya-develop cooperation. There are human relationships within it. Work more dynamic job-disc because it is done together, rotating and a compromise. Of course according to their expertise. The boarding culture seems to follow the trend initiated Theory Z William Ouchi.

\subsection{Pesantren Culture, Togetherness Culture}

But more of a group. Shared responsibility in a group tied true friendship. Supervision is not only in the form of formalistic activity, such as rules governing the management of the organization, but more than that. Supervision is it that one relationship with human dignity. When employees in its duty to uphold the values of our common humanity. When you run your control with not oppress and repress employees. When the rules governing the system and reflect the values of human dignity. Activity monitoring goes articulate and humane. Understanding of supervision should not be interpreted narrowly limited to the rules, but that which upholds human values. Supervision is not only in the form of formalistic activity, such as rules governing the management of the organization, but more than that. Supervision is it that one relationship with human dignity. When employees in its duty to uphold the values of our common humanity. When you run your control with not oppress and repress employees.

When the rules governing the system and reflect the values of human dignity. Activity monitoring goes articulate and humane. Understanding of supervision should not be interpreted narrowly limited to the rules, but that which upholds human values. Supervision is not only in the form of formalistic activity, such as rules governing the management of the organization, but more than that. Supervision is it that one relationship with human dignity. When employees in its duty to uphold the values of our common humanity.

When you run your control with not oppress and repress employees. When the rules governing the system and reflect the values of human dignity. Activity monitoring goes articulate and humane. Understanding of supervision should not be interpreted narrowly limited to the rules, but that which upholds human values. When you run your control with not oppress and repress employees.
When the rules governing the system and reflect the values of human dignity. Activity monitoring goes articulate and humane. Understanding of supervision should not be interpreted narrowly limited to the rules, but that which upholds human values. When you run your control with not oppress and repress employees. When the rules governing the system and reflect the values of human dignity. Activity monitoring goes articulate and humane. Understanding of supervision should not be interpreted narrowly limited to the rules, but that which upholds human values.

Supervision related to honesty. Conducting business activities should be done with honesty. Dishonesty will degrade human dignity. When the dignity trampled on, oppressed, tyrannized, destroyed for any reason, the name of religion though. This is the culture of the students. A culture that upholds human values in conducting business activities. Treating employees (students) are not within the boundaries of formal ties, but more than that. Not only limited to the humane treatment as a family, but is included in the bonding recesses God. Ties that uphold the values of human dignity. Ties that missed in the arms of God. The family is not just a social institution in its most minor. The family is fertile ground for any man to gain or harvest any perspective that might be about him. Therefore, the perspective of human life is so broad and deep. Relationships students-kijaji and societasnya not narrowed in relation merely material, but there are human relations, relations of friendship, a relationship of respect. Relationships are formed mistaqan ghalidhan (strong lasting bond), Sakinah (calmness perennial), mawaddah (deep love) and mercy (kerahmatan that memanusiawi).

In the family or in the sense of family we learn about the meaning of "we" and "I-thou". A good family is a family that gives its members the possibility to strengthen the understanding of who "I" and awards the presence of another person ( "you") as a part of himself so as to form a bond of "us". The meaning of "we" is not primarily the number of family members around schools. "We" is a truth about the presence of myself and others. "We" is the knowledge of everyday life, where I have the expectation or the hope itself. In the "we" I do not disappear, but even more memanusiawi. When students enter the realm of the family section, which upholds the values of the dignity of our common humanity, justice will be found. Justice is the entirety of each component of the business activities that run each task well. 
Truth be planning to live together in business activities. When the system is in moving the business is going well and hormonis, when it happened beauty in order. Order based on justice. Tata fair thus very concrete. Adil confirm the truth of living together system shall be so arranged. Order called fair when the life and dignity of every human being on defense and glorified. Theory $\mathrm{Z}$ are good dkemas Wllliam Ouchi reflect and treats "human" in human togetherness. When that happens the beauty in order. Order based on justice.

Tata fair thus very concrete. Adil confirm the truth of living together system shall be so arranged. Order called fair when the life and dignity of every human being on defense and glorified. Theory $\mathrm{Z}$ are good dkemas Wllliam Ouchi reflect and treats "human" in human togetherness. When that happens the beauty in order. Order based on justice. Tata fair thus very concrete. Adil confirm the truth of living together system shall be so arranged. Order called fair when the life and dignity of every human being on defense and glorified. Theory $\mathrm{Z}$ are good dkemas Wllliam Ouchi reflect and treats "human" in human togetherness.

\subsection{Production Process by Santri (Student)}

The students at the school not only provided the ability to religion, but taught entrepreneur. Enterprises producing coffee beans, fries and coffee powder with the brand "coffee prayer". An interesting label for incorporating elements of prayer in the production process. Coffee before it is distributed to markets processed by reading prayers Manaqib, istighasah, and khatmil Qur'an (worry AlQuran). A deep rooted tradition inherent in the pesantren community. They do riyadhah (internal business) so that the students bring a blessing coffee production. Blessed worldly (material) and ukhrawiyah (immaterial-reward). Efforts riyadhah (mental effort) are not meant for the commercialization of religion or religious justification for business purposes, but no more than a tradition of students and schools are still attached in the realm of world ilahiyat (divinity). Perhaps, the public will see the uniqueness of the coffee production students (stantri coffee) (coffee 4 in $1 /$ Coffee + Sugar + Milk + Prayer $)$.

This uniqueness can be fruitful attractiveness. Which gave birth to the attractiveness of the appeal and the stimulus to buy. Public appeal to buy coffee the students not only a matter of taste (teste) pure coffee without the mix, but the prayer. Pray for the students and their kiai. Prayer can be a suggestion buyer to seek blessings. Production is an effort to create wealth through the exploitation of man against the resources of the environment for the benefit and usefulness of the people. Its function is to produce, create goods, increase the added value (values). Important issue that must be implemented is a function of the production in accordance with the spirit spiritualistic uphold the values of ethics, quality and productivity. Orientation formed is to achieve a harmonious and sustainable relationship for all parties concerned in the production process. Therefore, the purpose of production is at least: First, the production can meet the needs of every individual. Ekononomi or production activities to develop the values of ethics, quality and productivity. Islam highly appreciate these components. Inside there is a factor of production resourcefully (professionalism) and ihsan (fairness, honesty and responsibility).

The struggle these two factors become a requirement in the process or production activities. Second, realize the independence of the people. Structuring the network and the production target must be done in order to increase productivity. Business activities relate and are concerned with the environment. The neighborhood is a system. Inside there is a system of variables or factors that are in the environment and related business. In other words, business is basically an attempt to manage the economic resources available in the environment. Therefore, there is interaction between man, the environment and business. Understanding the human character, the business environment to be an important thing to note.

Before starting a business, business systems must be built. This system as a guide and reference in conducting business activities. Business system consisting of components interconnected to achieve a goal. The system runs from the input, process and output. A business system that is driven by the values which may be different from business systems in general. Including input categories are: First, entrepreneurial students. Pupils not only given religious knowledge, but equipped with how to build entrepreneurship based on spiritual values. Second, the expertise of HR (Human Resources). Treats people as the most important sources in moving the coffee commodity business. Man with all the characteristics inherent in it is the determinant factor affecting productivity.

Theory Z William Ouchi very interesting to be applied. When toughest of recruits (boarding school admission test), students selected entry in the pesantren community must meet the qualifications and requirements that have been determined. 
Qualifications and terms of good morals and have an entrepreneurial spirit. Debriefing students of religion meant for printing high integrity. Recitals, discussions about religion and plurality. Entrepreneurship training and insight into important given the students. When the training is done, the students perform entrepreneurial practices in coffee. In other words, training and practice carried out simultaneously. Starting from the production process, teste coffee, distribute to manage finances. Third, the capital. Capitalization is done by measuring the ability to carry out activities of the coffee business. The production process includes: production management, human resource management, marketing management, and financial management. All these processes are done students. Melatakkan human factor as something very big and influential in the process of production management, human resources and financial management.

Application of Theory $\mathrm{Z}$ was initiated by William Ouchi very relevant for application. The process is done properly process the business in general. The only difference is the confidence (trust), kearaban (intimacy), flexibility (subtlety), toughness and honesty in conducting these activities.

\section{CONCLUSION}

Communal culture (social and cultural organizations) in boarding resembles with Japanese culture. This boarding communal culture follow the trend of seven basic principles wake Theory $\mathrm{Z}$ William Ouchi in his. Putting a man's position as a determinant factor in increasing productivity. Productivity that upholds human dignity.

\section{ACKNOWLEDGMENTS}

The authors would like to thank the Universitas Muhammadiyah Gresik for their financial support and the completion of this research.

\section{REFERENCES}

[1] Cushway and Lodge. 1995. Organizational Behavior and Design. (Translation). Publisher Elex Media Komputindo

[2] Daniel A. Wren Arthur G. Bedeian, Wiley John Wiley \& Son, 2009. The Evolution of Management Thought. Inc.

[3] Herman S. 2009. Culture and Modification Theory $\mathrm{Z}$ in Indonesia. Journal BETA (Business Economics \& Accounting) Vol. 7. No. 2
[4] Ouchi W. 1987. Theory Z, How Americans Faced with Japan in the Business World. Andamera Library

[5] Pierce, Gordon A. 1991. Management Philosophies: What Comes After Theory Z? Journal of System Management. June 1991. ABI / INFORM Global

[6] Sullivan, Jeremiah J. 1983. A Critique of Theory Z. Academy of Management. The Academy of Management Review. ABI / INFORM Global

[7] Wasono, R. 2016. Role of Theory Z In Higher Education Quality Improvement Muhammadiyah. The 3rd University Research Colloquium 2016

[8] Wasono, R. 2018. Human Resource Management Based Muhammadiyah universities through the implementation of Organizational Culture Theory Z. Journal 